Research Paper

\title{
Thermoeconomic analysis of hydrogen incorporation in a biodiesel plant
}

\author{
Ronney Arismel Mancebo Boloy ${ }^{\mathrm{a}, \mathrm{b}, *}$, Marcio Evaristo Silva ${ }^{\mathrm{b}}$, Atilio Erazo Valle ${ }^{\mathrm{b}}$, José Luz Silveira ${ }^{\mathrm{b}}$, \\ Celso Eduardo Tuna ${ }^{\mathrm{b}}$
}

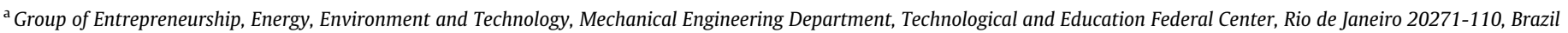

${ }^{\mathrm{b}}$ Optimization and Energetic Systems Group (GOSE), Department of Energy, College of Engineering at Guaratinguetá, São Paulo State University (UNESP),

Av Dr. Ariberto Pereira da Cunha, 333, Pedregulho, Guaratinguetá, 12.516-410 SP, Brazil

\section{H I G H L I G H T S}

- Exergetic contribution of all equipments in the BHPP is determined.

- Hydrogen production in the BHPP makes possible the energetic use of glycerine.

- Simultaneous production of biodiesel and hydrogen is a feasible alternative.

\section{A R T I C L E I N F O}

\section{Article history:}

Received 2 June 2016

Revised 6 October 2016

Accepted 27 October 2016

Available online 28 October 2016

\section{Keywords:}

Thermoeconomic

Hydrogen

Biodiesel

Functional diagram

Glycerine

Cost

\begin{abstract}
A B S T R A C T
The paper develops a methodology that uses the thermoeconomic functional diagram applied for allocating cost of products obtained by the plant and afterwards demonstrates how it is possible to calculate the marginal cost in US\$/kW h of the production. The methodology which was adopted includes the plant exergetic analysis development, the function system identification through physical diagram of the plant, construction of the Thermoeconomic Functional Diagram and the determination of the expressions for the plant's exergetic functions. The methodology also includes the determination of some parameters such as, investments, maintenance, operation, raw materials (canola oil, catalysts, methanol, glycerine and natural gas) and utility costs (electricity and steam water). As a result, it can be said that the simultaneously production of biodiesel and hydrogen is a suitable technology to minimize biodiesel production cost. About $6 \%$ of the thermoeconomic cost of biodiesel production was diminished when compared to the values previously published in the present literature. In relation to the hydrogen production thermoeconomic costs, the values are closer when they are compared to the ones which were identified in the literature. As a contribution to the scientific knowledge, it can be said that the obtained results shows the high performance of simultaneous biodiesel and hydrogen production, especially when glycerine is further processed into valuable energetic matter, in other words, considering economic aspects associated with the exergy conception, in order to develop a tool to assist the equipment operation, as well as to optimize the biodiesel plant design. Also shows that in a biodiesel production plant the hydrogen technology is more sustainable than the traditional one. The paper aims to innovate the production process of biodiesel by incorporating the hydrogen production process through glycerine steam reforming.

(c) 2016 Elsevier Ltd. All rights reserved.
\end{abstract}

\section{Introduction}

The competitiveness of biodiesel production has become a very important topic of research by the fact that it is largely used in the energetic and transport sector. An earlier paper which aims to study the competitiveness of biodiesel production was performed by

* Corresponding author at: Group of Entrepreneurship, Energy, Environment and Technology, Mechanical Engineering Department, Technological and Education Federal Center, Rio de Janeiro 20271-110, Brazil.

E-mail address: ronney.boloy@cefet-rj.br (R.A.M. Boloy).
Zhang et al. [1,2], where the economic feasibilities of four continuous processes to produce biodiesel were assessed. Later, Coronado et al. [3] applied the thermoeconomic methodology to study a biodiesel production plant, in which were determined the irreversibilities in each component of the plant, allowing the achievement of biodiesel and glycerine production costs. The paper includes the costs of carbon credits for the carbon dioxide, which is not released to the atmosphere. Kligerman and Bouwer [4] focuses on the feasibility of utilizing wastewater to cultivate algae for the production of biodiesel in Brazil. Johari et al. [5] seeks to critically examine challenges afflicting the biodiesel industry in Malaysia by analysing the 


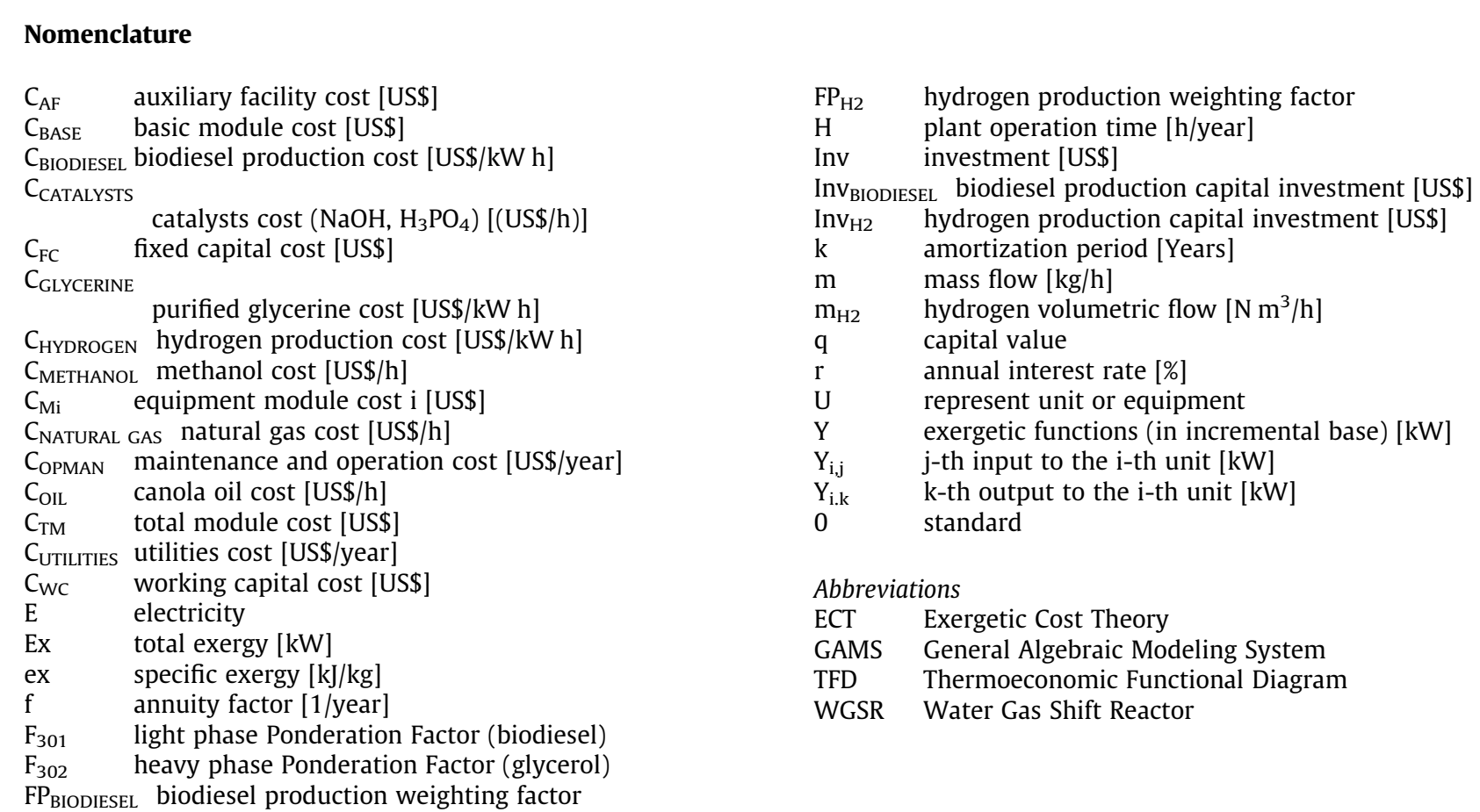

key policies, framework and institutions in the country. Olkiewicz et al. [6] studied the influence of different reaction variables on the biodiesel yield using [mimC4SO3H][SO3CF3] as a catalyst. One common drawback in the competitiveness of biodiesel production is the energetic use of glycerine via steam reforming. Recently, significant advances in the glycerine steam reforming for hydrogen production have been achieved [7-10]. Best conditions for steam reforming were studied by Adhikari et al. [11]. Nonlinear programming model implemented in GAMS considering the ideal gaseous phase and formation of solid carbon was also proposed by Rossi et al. [12]. For hydrogen use in low temperature proton exchange fuel cell, it has been acknowledged that optimal production conditions were temperature equal to $1000 \mathrm{~K}$ and steam to glycerol molar ratio equal to 6 [13]. For high temperature proton exchange membrane fuel cells the optimal conditions were: higher carbon monoxide tolerances and higher reform temperatures [13]. Thermodynamic analysis of glycerol steam reforming with hydrogen or carbon dioxide co-fed as carbon gasifying agents in order to mitigate carbon deposition was performed by Cheng et al. [14]. In the scientific literature, there are methodologies applying the thermoeconomic analysis to the study of a biodiesel production plant. Previously a paper mentioning the Exergy Cost Theory uses was performed by Mora [15], where a new sustainability indicator was introduced to analyse a biodiesel production plant. Integrate glycerin steam reform process in a biodiesel plant is a simple way to produce simultaneously biodiesel and hydrogen with low costs. Additionally, incorporation of hydrogen production process in a biodiesel plant opens conditions for cogeneration systems introduction in the plant, taking advantage of the production low costs. In this paper, a detailed thermoeconomic analysis of hydrogen production process incorporation in a biodiesel plant is investigated, and the reason for its relatively low costs is discussed.

\section{Methodology}

This paper uses of a methodology, which aims the building of the thermoeconomic functional diagram of biodiesel production plant, also seeks the determination of the production costs of hydrogen and biodiesel. A biodiesel production plant, which was studied and simulated using Hysys software by Boloy et al. [16], was used as benchmark.

Thermoeconomic analysis is defined as an appropriate combination of exergetic and economic analysis, where exergetic incremental costs are associated to each flow of the system. Recently, two thermoeconomic methodologies have been used aiming the study of thermal systems: Exergetic Cost Theory (ECT) [17] and Thermoeconomic Functional Diagram (TFD) [18-21].

\subsection{Identification of systems functions. Construction of physical diagram}

To identify the systems functions within the plant, a physical diagram of simultaneous production of biodiesel and hydrogen was built as shown in Figs. 1 and 2.

\subsection{Construction of the thermoeconomic functional diagram}

Figs. 3 and 4 show the thermoeconomic functional diagram. The diagram is composed by functional lines of frontier and geometric figures (equipments and process of the plant). These geometric figures are linked with lines representing the functions in terms of exergy unit increments [22-24]. According to Silveira et al. [22] the notation used in the Thermoeconomic Functional Diagram is:

U - Represent unit or equipment;

$\mathrm{Y}$ - Exergetic functions (in incremental base);

$Y_{i, j}-j$-th input to the i-th unit;

$Y_{i . k}-k$-th output to the i-th unit.

\subsection{Determination of the expressions for the plant's exergetic functions}

In order to calculate the exergetic functions, all the losses at the pipes will not be considered. The formulated expressions were 


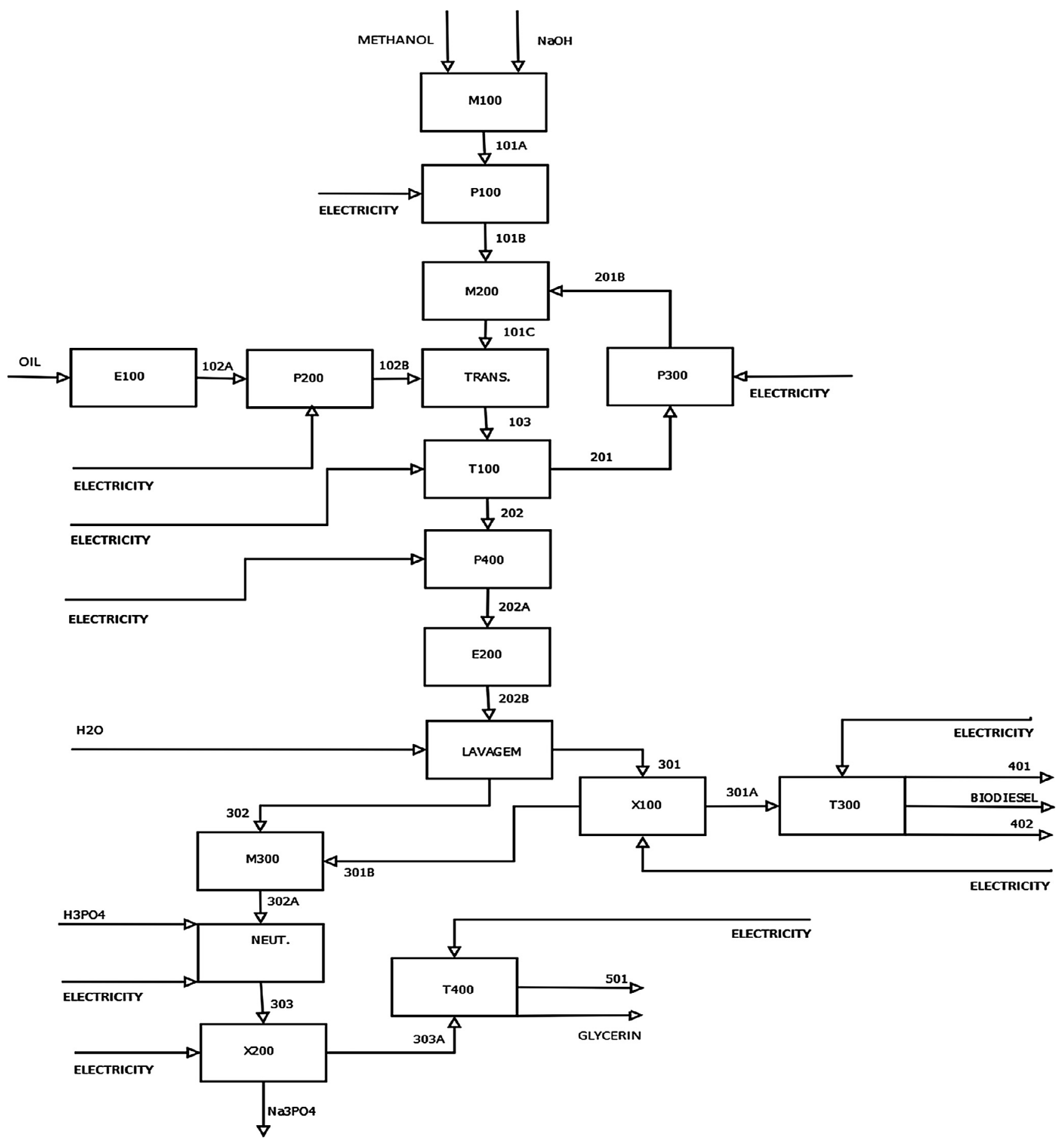

Fig. 1. Physical diagram of simultaneous production of biodiesel and hydrogen.

based on physical and thermoeconomic functional diagram and depends on thermodynamic properties and the exergetic values obtained in the plant by Boloy et al. [16]. The expressions are shown below.

Unit 1: Mixer M100

$\mathrm{Y}_{1,1}=\mathrm{Y}_{0.1}=\mathrm{E}_{\mathrm{XMETHANOL}}$

$\mathrm{Y}_{1,2}=\mathrm{Y}_{0.2}=\mathrm{E}_{\mathrm{XNaOH}}$
$\mathrm{Y}_{1.1}=\mathrm{m}_{\text {methanol }} *\left(e x_{101 A}-e x_{\text {methanol }}\right)+\mathrm{m}_{\mathrm{NaOH}} *\left(e x_{101 A}-e x_{\mathrm{NaOH}}\right)$

Unit 2: Pump P100

$\mathrm{Y}_{2,1}=\mathrm{Y}_{1.1}$

$Y_{2,2}=Y_{0.3}$

(1) $\quad \mathrm{Y}_{2.1}=E x_{101 \mathrm{~A}}-E x_{101 B}$

Unit 3: Mixer M200
$\quad \mathrm{Y}_{3,1}=\mathrm{Y}_{2.1}$ 


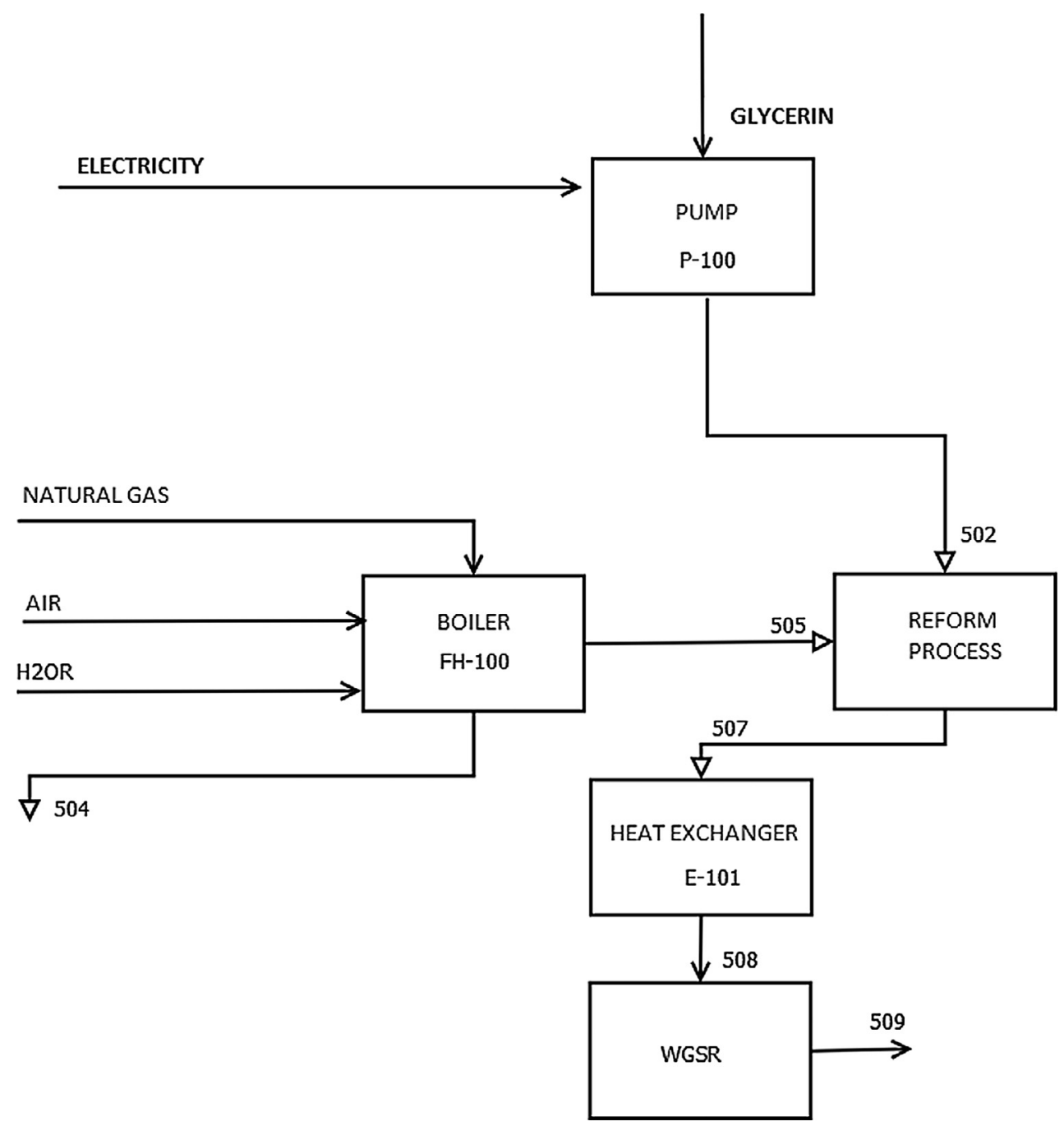

Fig. 2. Physical diagram of simultaneous production of biodiesel and hydrogen. Cont.
$\mathrm{Y}_{3,2}=\mathrm{Y}_{8.1}$
(7) Unit 7: Distillation Tower T100
$\mathrm{Y}_{3.1}=m_{101 B} *\left(e x_{101 C}-e x_{101 B}\right)+m_{201 B} *\left(e x_{101 C}-e x_{201 B}\right)$$$
\mathrm{Y}_{7,1}=\mathrm{Y}_{6.1}
$$
Unit 4: Heat Exchanger E100
$\mathrm{Y}_{4,1}=\mathrm{Y}_{0.4}=E x_{\text {OIL }}$
(9) $\quad \mathrm{Y}_{7.1}=\mathrm{m}_{201} *\left(\mathrm{ex}_{103}-\mathrm{ex}_{201}\right)$
$Y_{4,2}=Y_{0.5}$
(10) $\quad \mathrm{Y}_{7.2}=\mathrm{m}_{202} *\left(\mathrm{ex}_{202}-\mathrm{ex}_{103}\right)$
$\mathrm{Y}_{4.1}=E x_{\text {OIL }}-E x_{102 A}$
Unit 5: Pump P200
Unit 8: Pump P300
$\mathrm{Y}_{8,1}=\mathrm{Y}_{7.1}$
$\mathrm{Y}_{5,1}=\mathrm{Y}_{4.1}$
(12) $\quad Y_{8,2}=Y_{0.8}$
$\mathrm{Y}_{5,2}=\mathrm{Y}_{0.6}$
(13) $\quad Y_{8.1}=E x_{201}-E x_{201 B}$
$\mathrm{Y}_{5.1}=\mathrm{EX}_{102 \mathrm{~A}}-E x_{102 B}$
Unit 6: Transesterification Reactor R100
$\mathrm{Y}_{9,1} \frac{\text { Unit 9: Pump P400 }}{=\mathrm{Y}_{7.2}}$
$\mathrm{Y}_{6,1}=\mathrm{Y}_{3.1}$
$Y_{6,2}=Y_{5.1}$
$\mathrm{Y}_{6.3}=\mathrm{E} 3$
$\mathrm{Y}_{0.10}=\mathrm{Y}_{9,2}$
$\mathrm{Y}_{6.1}=\mathrm{Ex}_{102 \mathrm{~B}}+\mathrm{Ex}_{101 \mathrm{C}}-\mathrm{Ex}_{103}$
(18) $\quad Y_{10.1}=E x_{202 A}-E x_{202 B}$ 


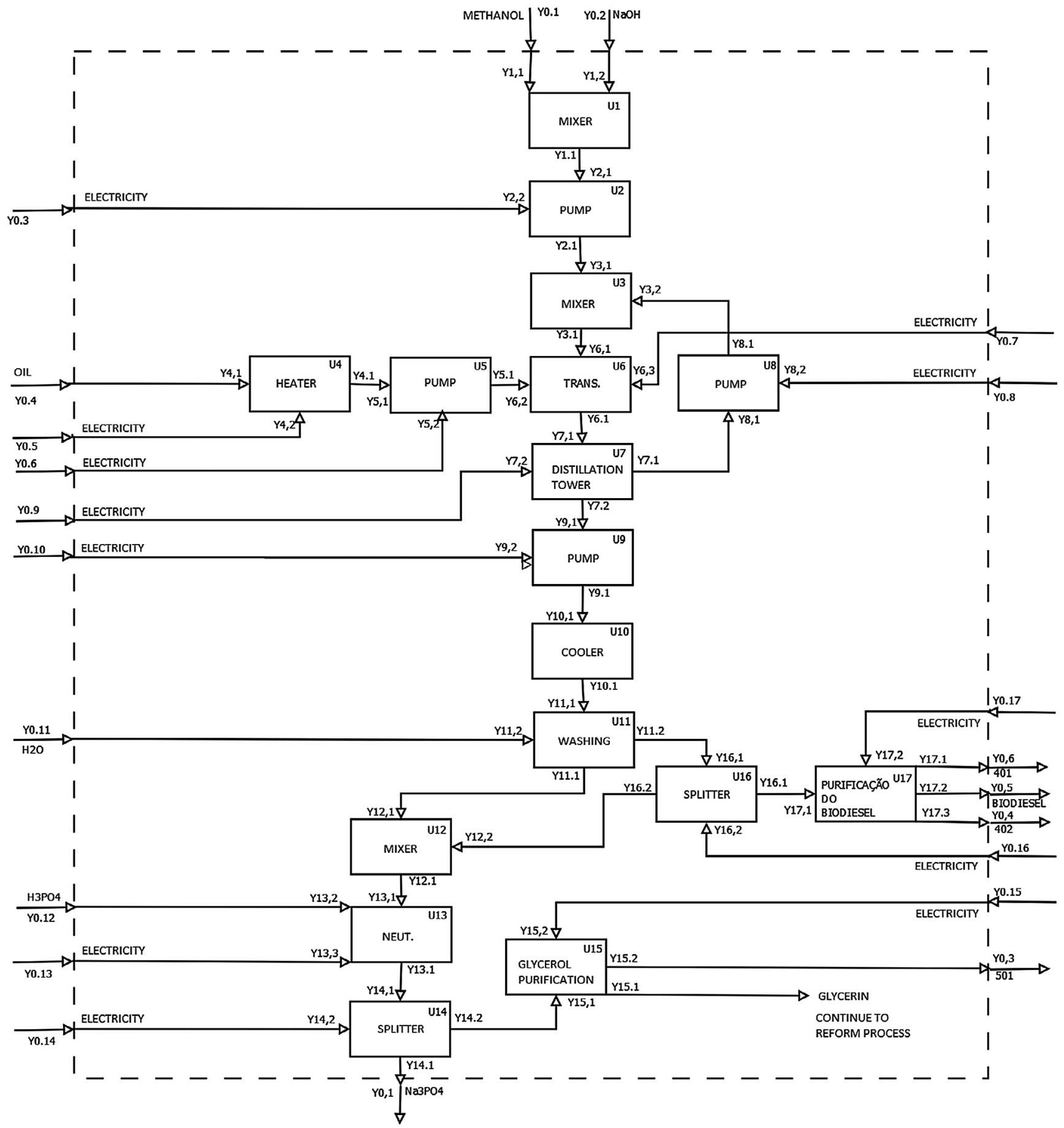

Fig. 3. Thermoeconomic functional diagram of simultaneous production of biodiesel and hydrogen.

Unit 11: Washing Process T100

$\mathrm{Y}_{11,1}=\mathrm{Y}_{10.1}$

$\mathrm{Y}_{11,2}=\mathrm{Y}_{0.11}=E x_{\mathrm{H} 2 \mathrm{O}}$

$\mathrm{Y}_{11.1}=F_{302} m_{\mathrm{H} 2 \mathrm{O}}\left(e x_{302}-e x_{\mathrm{H} 2 \mathrm{O}}\right)+F_{302} m_{202 B}\left(e x_{202 B}-e x_{302}\right)$

$\mathrm{Y}_{11.2}=F_{301} m_{\mathrm{H} 2 \mathrm{O}}\left(e x_{301}-e x_{\mathrm{H} 2 \mathrm{O}}\right)+F_{301} m_{202 B}\left(e x_{301}-e x_{202 B}\right)$

$F_{301}=\frac{m_{301}}{m_{202 B}+m_{\mathrm{H} 20}}$
$F_{302}=\frac{m_{302}}{m_{202 B}+m_{\mathrm{H} 20}}$

where

$\mathrm{F}_{301}$ : Ponderation Factor in light phase (Biodiesel)

$\mathrm{F}_{302}$ : Ponderation Factor in heavy phase (Glycerol)

Unit 12. Mixer M300

$\mathrm{Y}_{12,1}=\mathrm{Y}_{11.1}$

$\mathrm{Y}_{12,2}=\mathrm{Y}_{16,2}$ 


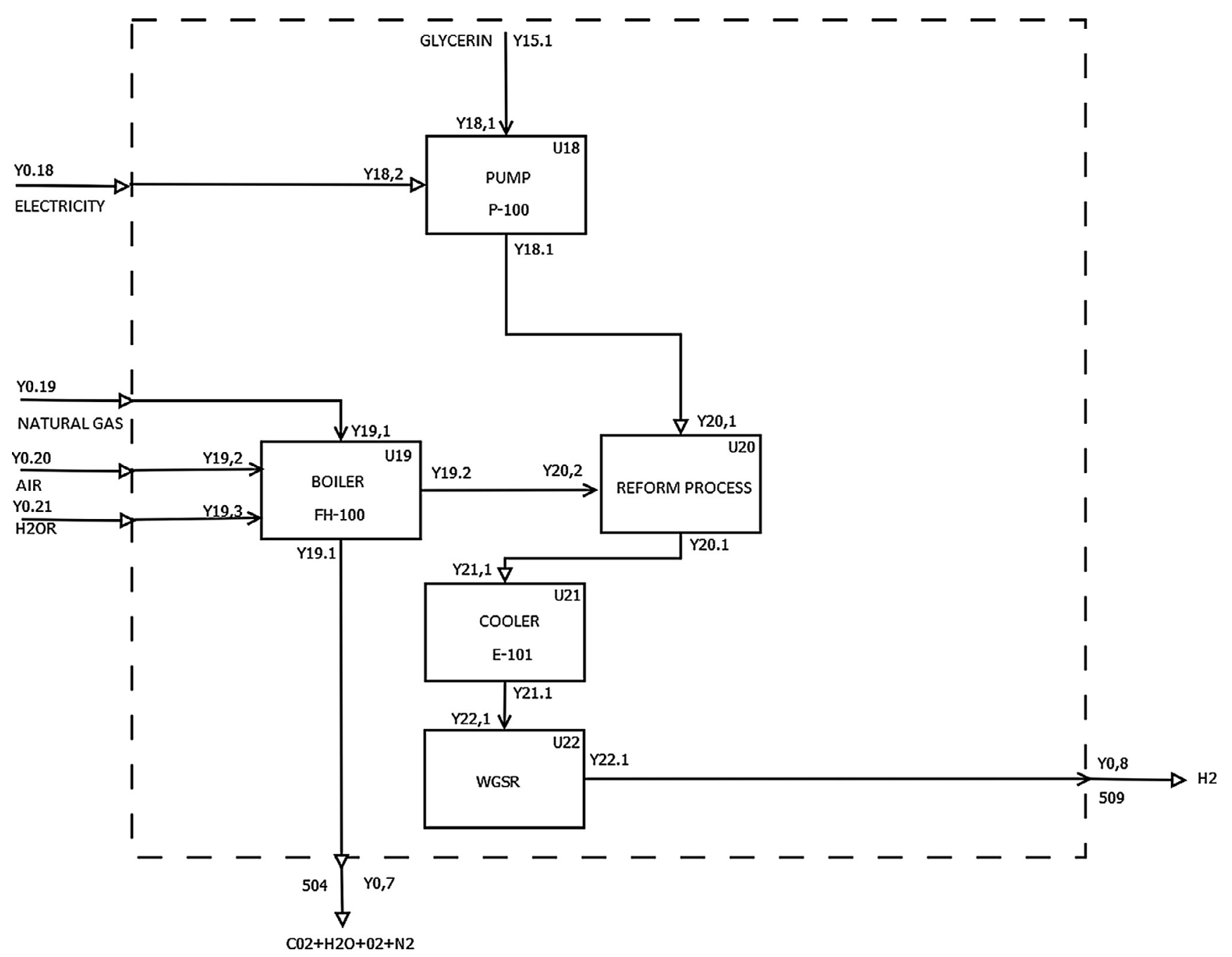

Fig. 4. Thermoeconomic functional diagram of simultaneous production of biodiesel and hydrogen.

$\mathrm{Y}_{12.1}=E x_{302}+E x_{301 B}-E x_{302 A}$

Unit 14: Neutralization Reactor R200

$\mathrm{Y}_{13,1}=\mathrm{Y}_{12.1}$

$\mathrm{Y}_{13,2}=\mathrm{Y}_{0.12}=E x_{\mathrm{H} 3 \mathrm{PO}} 4$

$\mathrm{Y}_{13,3}=\mathrm{Y}_{0.13}$

$\mathrm{Y}_{13.1}=E x_{\mathrm{H} 3 \mathrm{PO} 4}+E x_{302 A}-E x_{303}$

Unit 14: Splitter $X 200$

$\mathrm{Y}_{14,1}=\mathrm{Y}_{13.1}$

$\mathrm{Y}_{14,2}=\mathrm{Y}_{0.14}$

$\mathrm{Y}_{14.1}=E x_{303}-E x_{303 \mathrm{~A}}$

$\mathrm{Y}_{14.2}=E x_{\mathrm{Na} 3 \mathrm{PO} 4}=Y_{0,1}$

Unit 15: Distillation Tower T400

$\mathrm{Y}_{15,1}=\mathrm{Y}_{14.2}$

$\mathrm{Y}_{15,2}=\mathrm{Y}_{0.15}$

$\mathrm{Y}_{15.1}=m_{\text {GLYCERIN }}\left(e x_{303 A}-e x_{\text {GLYCERIN }}\right)$

$Y_{15.2}=E x_{501}=Y_{0,3}$
Unit 16: Splitter $X 100$

$\mathrm{Y}_{16,1}=\mathrm{Y}_{11.2}$

$\mathrm{Y}_{16,2}=\mathrm{Y}_{0.16}$

$Y_{16.1}=m_{301 A}\left(e x_{301}-e x_{301 A}\right)$

$Y_{16.2}=m_{301 B}\left(e x_{301}-e X_{301 B}\right)$

Unit 17: Distillation Tower T300

$\mathrm{Y}_{17,1}=\mathrm{Y}_{16.1}$

$\mathrm{Y}_{17,2}=\mathrm{Y}_{0.17}$

$Y_{17.1}=E x_{401}=Y_{0,6}$

$Y_{17.2}=E x_{\text {BIODIESEL }}=Y_{0,5}$

$Y_{17.3}=E x_{402}=Y_{0,4}$

Unit 18: Pump P-100

$\mathrm{Y}_{18,1}=\mathrm{Y}_{15.1}$

$\mathrm{Y}_{18,2}=\mathrm{Y}_{0.18}$

$\mathrm{Y}_{18.1}=E x_{\text {GLYCERIN }}-E x_{502}$ 
Unit 19: Boiler $\mathrm{FH}-100$

$\mathrm{Y}_{19,1}=\mathrm{Y}_{0.19}=E x_{\text {NATURALGAS }}$

$\mathrm{Y}_{19,2}=\mathrm{Y}_{0.20}=E x_{A I R}$

$\mathrm{Y}_{19,3}=\mathrm{Y}_{0.21}=E x_{\mathrm{H} 2 \mathrm{OR}}$

$Y_{19.1}=E x_{504}=Y_{0,7}$

$\mathrm{Y}_{19.2}=m_{505}\left(e x_{505}-e x_{\mathrm{H} 2 \mathrm{OR}}\right)$

Unit 20: Reform Process

$\mathrm{Y}_{20,1}=\mathrm{Y}_{18.1}$

$\mathrm{Y}_{20,2}=\mathrm{Y}_{19.2}$

$Y_{20.1}=m_{505}\left(e x_{507}-e x_{505}\right)+m_{G L Y C E R I N}\left(e x_{507}-e x_{G L Y C E R I N ~}\right)$

Unit 21: Heat Exchanger E101

$\mathrm{Y}_{21,1}=\mathrm{Y}_{20.1}$

$Y_{21.1}=E x_{507}-E x_{508}$

Unit 22: WGSR

$\mathrm{Y}_{22,1}=\mathrm{Y}_{21.1}$

Table 1

Investment, maintenance, and operation cost [16].

\begin{tabular}{lllll}
\hline & UM & Hydrogen & Biodiesel & Total \\
\hline Inv & US\$ & 836000.30 & 1764686.87 & 2600687 \\
C $_{\text {OPMAN }}$ & US\$year & 25080.0086 & 838949.49 & 864029.50 \\
\hline
\end{tabular}

Table 2

Raw materials costs.

\begin{tabular}{|c|c|c|c|c|}
\hline Raw material & UM & Cost & UM & Cost \\
\hline Methanol & US\$/kg & 0.632 & $\mathrm{US} \$ / \mathrm{h}$ & 74.26 \\
\hline Canola oil & US\$/kg & 0.99 & $\mathrm{US} \$ / \mathrm{h}$ & 1039.50 \\
\hline $\mathrm{NaOH}$ & US\$/kg & 7.95 & US\$/h & 79.5 \\
\hline $\mathrm{H}_{3} \mathrm{PO}_{4}$ & US\$/kg & 3.3 & $\mathrm{US} \$ / \mathrm{h}$ & 27.06 \\
\hline Natural gas & $\mathrm{R} \$ / \mathrm{h}$ & 24.92 & $\mathrm{US} \$ / \mathrm{h}$ & $11.33^{\mathrm{a}}$ \\
\hline Total & US\$/kg & 12.312 & $\mathrm{US} \$ / \mathrm{h}$ & 1231.65 \\
\hline
\end{tabular}

a $1 \mathrm{US} \$=2.20 \mathrm{R} \$$.

Table 3

Utility costs in biodiesel production.

\begin{tabular}{ll}
\hline Utilities & Costs (US\$/year) \\
\hline Electricity + Steam water & 86787.88 \\
\hline
\end{tabular}

$\mathrm{Y}_{22.1}=E x_{509}$

2.4. Investments, maintenance, operation, utility, and raw material costs determination

The investments, maintenance, and operation costs were calculated using as benchmark the papers published by Zhang et al. [2] and Coronado et al. [3]. The paper did not consider the hydrogen storage cost because the main objective is to determine the hydrogen production cost.

The biodiesel production investment cost (Eq. (76)) can be defined as the sum of the fixed capital cost (Eq. (77)) and the working capital cost (15\% of the fixed capital cost) (Eq. (78)). Moreover the fixed capital cost is defined as the sum of total module cost (Eq. (79)) (contingencies and feed) and the facilities costs auxiliary $(30 \%$ of the total basic module cost).

$\operatorname{InV}_{\text {BIODIESEL }}=C_{F C}+C_{W C}$

$\mathrm{C}_{\mathrm{FC}}=\mathrm{C}_{\mathrm{TM}}+\mathrm{C}_{\mathrm{AF}}$

$\mathrm{C}_{\mathrm{WC}}=0,15 * \mathrm{C}_{\mathrm{FC}}$

$\mathrm{C}_{\mathrm{TM}}=1,18 * \sum_{i=1}^{n} \mathrm{C}_{\mathrm{M}}$

$\mathrm{C}_{\mathrm{AF}}=0,3 * \mathrm{C}_{\mathrm{Base}}$

where

$\mathrm{C}_{\mathrm{FC}}$ : Fixed capital cost (US\$);

$\mathrm{C}_{\text {WC }}$ : Working capital cost (US\$);

$\mathrm{C}_{\mathrm{TM}}$ : Total module cost (US\$);

$\mathrm{C}_{\mathrm{AF}}$ : Auxiliary facility cost (US\$);

$\mathrm{C}_{\mathrm{BASE}}$ : Basic module cost (US\$);

$\mathrm{C}_{\mathrm{Mi}}$ : Equipment Module Cost i (US\$).

The hydrogen production investment cost (Eq. (81)) was estimated using the Bohem Method [25], in addition the steam reform system with hydrogen production ranges from $1 \mathrm{~N} \mathrm{~m}^{3} / \mathrm{h}$ to $1500 \mathrm{~N} \mathrm{~m}^{3} / \mathrm{h}$.

$\operatorname{Inv}_{\mathrm{H} 2}=400\left(\frac{m_{\mathrm{H} 2}}{750}\right)^{0.5304}$

where

$\mathrm{m}_{\mathrm{H} 2}$ : Volumetric flow of hydrogen $\left(\mathrm{N} \mathrm{m}^{3} / \mathrm{h}\right)$

The biodiesel production maintenance cost is considered as $6 \%$ of investment cost [2]. On the other hand for hydrogen production process the maintenance cost is considered as 3\% of the investment cost [26].

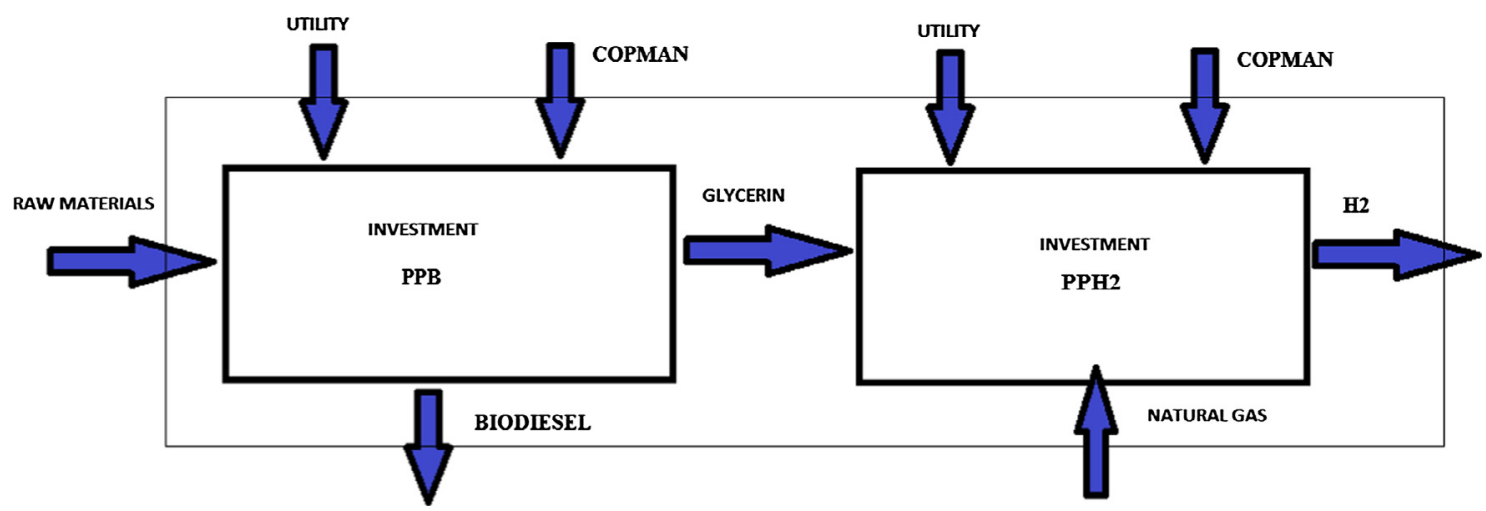

Fig. 5. Structural model based on costs for producing biodiesel and hydrogen. 
Table 4

Values of exergetic functions [kW] associated to simultaneous production of biodiesel and hydrogen.

\begin{tabular}{|c|c|}
\hline Exergetic functions & Value (kW) \\
\hline Y1,1 (methanol) & 731.30 \\
\hline Y1,2 (sodium hidroxide) & 5.20 \\
\hline Y1.1 & 8.45 \\
\hline $\mathrm{Y} 2,1$ & 8.45 \\
\hline $\mathrm{Y} 2,2$ & 0.02 \\
\hline Y2.1 & 0.30 \\
\hline $\mathrm{Y} 3,1$ & 0.30 \\
\hline $\mathrm{Y} 3,2$ & 6.33 \\
\hline Y3.1 & 4.46 \\
\hline Y4,1 (oil) & 12417.38 \\
\hline $\mathrm{Y} 4,2$ & 0.14 \\
\hline Y4.1 & 1.00 \\
\hline Y5,1 & 1.00 \\
\hline $\mathrm{Y} 5,2$ & 0.07 \\
\hline Y5.1 & 0.05 \\
\hline $\mathrm{Y} 6,1$ & 8.45 \\
\hline $\mathrm{Y} 6,2$ & 0.05 \\
\hline Y6,3 & 31.64 \\
\hline Y6.1 & 1049.56 \\
\hline $\mathrm{Y} 7,1$ & 1049.56 \\
\hline $\mathrm{Y} 7,2$ & 37.09 \\
\hline Y7.1 & 411.02 \\
\hline Y7.2 & 5072.15 \\
\hline Y8,1 & 411.02 \\
\hline Y8,2 & 0.02 \\
\hline Y8.1 & 6.33 \\
\hline Y9,1 & 5072.15 \\
\hline Y9,2 & 0.07 \\
\hline Y9.1 & 0.50 \\
\hline Y10,1 & 0.50 \\
\hline Y10.1 & 6.91 \\
\hline $\mathrm{Y} 11,1$ & 6.91 \\
\hline Y11,2 (water for washing process) & 0.15 \\
\hline Y11.1 & 5248.75 \\
\hline Y11.2 & 69.44 \\
\hline $\mathrm{Y} 12,1$ & 5248.75 \\
\hline $\mathrm{Y} 12,2$ & 64.98 \\
\hline Y12.1 & 0.67 \\
\hline $\mathrm{Y} 13,1$ & 0.67 \\
\hline Y13,2 (phosphoric acid) & 2.47 \\
\hline $\mathrm{Y} 13,3$ & 5.40 \\
\hline Y13.1 & 6.08 \\
\hline $\mathrm{Y} 14,1$ & 6.08 \\
\hline $\mathrm{Y} 14,2$ & 0.00 \\
\hline Y14.1 & 1.16 \\
\hline Y14.2 (sodium phosphate) & 64.75 \\
\hline $\mathrm{Y} 15,1$ & 64.75 \\
\hline Y15,2 & 4.13 \\
\hline Y15.1 (glycerine) & 18.10 \\
\hline Y15.2 & 39.23 \\
\hline $\mathrm{Y} 16,1$ & 69.44 \\
\hline $\mathrm{Y} 16,2$ & 0.45 \\
\hline Y16.1 & 48.71 \\
\hline Y16.2 & 64.98 \\
\hline $\mathrm{Y} 17,1$ & 48.71 \\
\hline $\mathrm{Y} 17,2$ & 328.72 \\
\hline Y17.1 & 69.60 \\
\hline Y17.2 (biodiesel) & 10991.53 \\
\hline Y17.3 & 460.30 \\
\hline $\mathrm{Y} 18,1$ & 18.10 \\
\hline Y18,2 & 0.02 \\
\hline Y18.1 & 0.04 \\
\hline Y19,1 (natural gas) & 168.53 \\
\hline $\mathrm{Y} 19,2$ (air) & 0.00 \\
\hline Y19,3 (water for reform process) & 1.75 \\
\hline Y19.1 (exhaust gases) & 129.28 \\
\hline Y19.2 & 62.99 \\
\hline Y20,1 & 0.04 \\
\hline $\mathrm{Y} 20,2$ & 62.99 \\
\hline Y20.1 & 67.47 \\
\hline $\mathrm{Y} 21,1$ & 67.47 \\
\hline Y21.1 & 77.94 \\
\hline $\mathrm{Y} 22,1$ & 77.94 \\
\hline Y22.1 (hydrogen) & 550.88 \\
\hline
\end{tabular}

The operation costs follows the considerations taken by Zhang et al. [2] and are listed below:

- Operators working for 49 weeks/year.

- The plant works in three shifts per day.

- The Operator salary is estimated in 47.85 US\$/year with the plant running $24 \mathrm{~h}$ per day.

Table 1 shows all investments, maintenance and operation plant costs. The values were updated using the inflation factor equals to 1.45 [16]. The inflation factor is defined as the ratio between the value of Chemical Engineering Plant Index for the year 2014 (572.8) and the value of Chemical Engineering Plant Index for the year 2000 (396) [16].

Table 2 shows the raw materials costs used in the plant. All costs are associated to the mass flow required for producing biodiesel and hydrogen [16].

Table 3 shows the biodiesel production utility costs. The values were obtained from the values suggested by Zhang et al. [2].

\subsection{Thermoeconomic costs determination of producing biodiesel and hydrogen}

The biodiesel and hydrogen production thermoeconomic costs are obtained through the structural model based on costs as shown in Fig. 5. The thermoeconomic costs includes investments, operation, maintenance, utilities, raw materials, and the exergetic functions values.

According to the structural model (Fig. 5) and reallocating the costs of production for both biodiesel and hydrogen taking into account the fact that the glycerine can be sold, the thermoeconomic costs of producing biodiesel and hydrogen would be defined as follows:

$$
\begin{aligned}
& \mathrm{C}_{\text {Biodiesel }}=\frac{\text { Inv }_{\text {BIODIESEL }} * \mathrm{f}}{\mathrm{H} * \mathrm{Y}_{17.2}}+\frac{\mathrm{C}_{\text {METHANOL }}}{\mathrm{Y}_{17.2}}+\frac{\mathrm{C}_{\text {CATALYSTS }}}{\mathrm{Y}_{17.2}}+\frac{\mathrm{C}_{\text {OIL }}}{\mathrm{Y}_{17.2}} \\
& +\frac{\mathrm{C}_{\text {UTILITIES }} * F P_{\text {BIO }}}{H * \mathrm{Y}_{17.2}}+\frac{\mathrm{C}_{\mathrm{OPMAN}} * F P_{\text {BIO }}}{H * \mathrm{Y}_{17.2}}
\end{aligned}
$$

$f=\frac{q^{k}(q-1)}{q^{k}-1}$

$q=1+\frac{r}{100}$

where

Inv $_{\text {BIODIESEL }}$ : Biodiesel production capital investment in (US\$);

Inv $_{\mathrm{H} 2}$ : Hydrogen production capital investment in (US\$);

f: Annuity factor (1/year);

q: Capital value;

r: Interest rate (\%);

$\mathrm{H}$ : Plant operation time (h/year);

$\mathrm{k}$ : Amortization period (years);

$\mathrm{FP}_{\text {BIODIESEL }}$ : Weighting factor for biodiesel production;

$\mathrm{FP}_{\mathrm{H} 2}$ : Weighting factor for hydrogen production; 


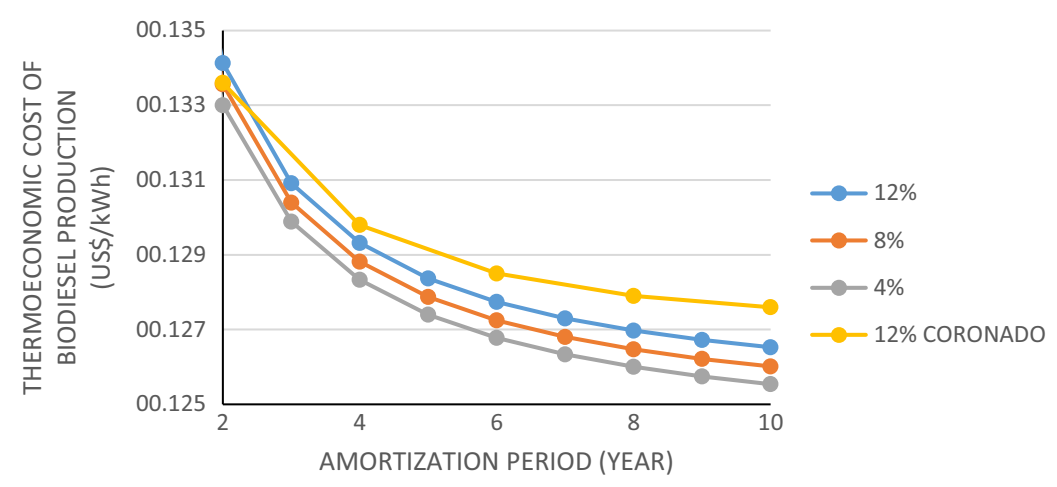

Fig. 6. Comparison of thermoeconomic costs for biodiesel production.

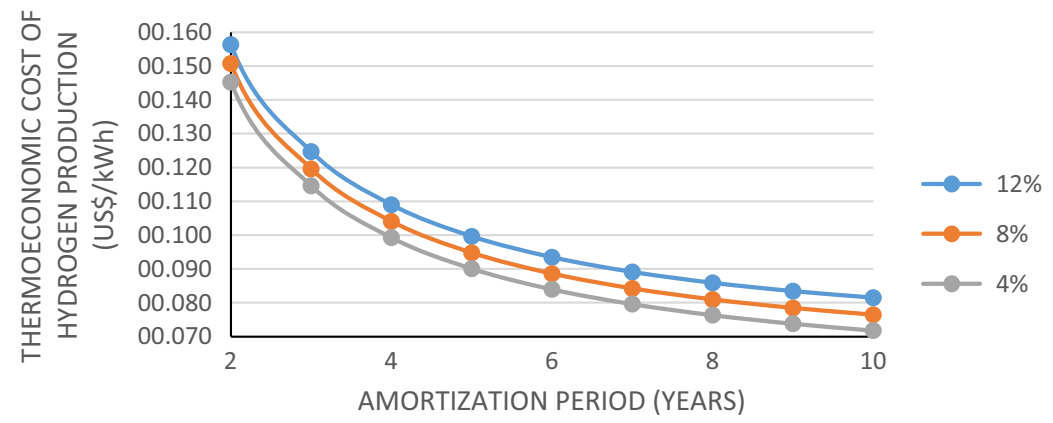

Fig. 7. Thermoeconomic costs for hydrogen production.

C NATURal gas: Natural gas cost in (US\$/h);

$\mathrm{C}_{\text {METHANOL }}$ : Methanol cost in (US $\left.\$ / \mathrm{h}\right)$;

Cóleo: Canola oil cost in (US\$/h);

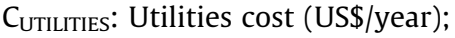

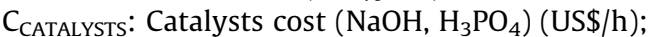

$\mathrm{C}_{\text {OPMAN }}$ : Maintenance and operation cost (US\$/year);

$\mathrm{C}_{\mathrm{GLYCERINE}}$ : Purified glycerine cost (US\$/kW h).

$\mathrm{Y}$ : Exergetic functions (in incremental base) in $(\mathrm{kW})$;

\section{Results and discussion}

The present paper main purpose is the thermoeconomic analysis of hydrogen incorporation in a Biodiesel plant. Which is a useful methodology which allows determining the values of exergetic functions and marginal costs of products in a given system.

Table 4 presents the values of exergetic functions associated to the units described in thermoeconomic functional diagram. With respect to the results presented in the table, it is observed that the canola oil (12417.38 kW), biodiesel (10991.53 kW) and hydrogen $(550.88 \mathrm{~kW})$ presents the highest values of exergetic functions. This fact is explained by the highest exergetic contribution provided to the system. This exergetic contribution is located in the transesterification reactor, in the distillation tower and in the steam reformer reactor.

Fig. 6 compares the values of biodiesel production thermoeconomic costs, where it can be inferred that the costs obtained in the simultaneous biodiesel and hydrogen production oscillates between $0.1255 \mathrm{US} \$ / \mathrm{kW} \mathrm{h}$ and $0.1341 \mathrm{US} \$ / \mathrm{kW} \mathrm{h}$. The new biodiesel production innovative technology demonstrates in a better way the thermoeconomic costs compared to those reported by Coronado in the previous work where biodiesel thermoeconomic costs were ranging between $0.1276 \mathrm{US} \$ / \mathrm{kWh}$ and
$0.1336 \mathrm{US} \$ / \mathrm{kW} \mathrm{h}[3]$. This decrease can be attained to the energetic glycerine usage for hydrogen production.

The hydrogen production thermoeconomic cost is sensitive to the glycerine purification process cost variation, this cost depends on the type of purification technology used, this paper presents a distillation tower, which leads the purified glycerine cost of $0.020 \mathrm{US} \$ / \mathrm{kW}$ h. Fig. 7 presents the hydrogen production thermoeconomic costs, these costs were ranging from $0.07 \mathrm{US} \$ / \mathrm{kW} \mathrm{h}$ $\left(2.22 \times 10^{-5} \mathrm{US} \$ / \mathrm{kJ}\right)$ to $0.16 \mathrm{US} \$ / \mathrm{kW} \mathrm{h}\left(4.72 \times 10^{-5} \mathrm{US} \$ / \mathrm{kJ}\right)$. As a method to compare, some authors such as Cruz et al. [27], reports hydrogen production cost equal to $1.74 \times 10^{-5}$ US $\$ / \mathrm{kJ}(0.0623$ US\$/ $\mathrm{kWh}$ ) [27], this value is similar to the lower value found in this paper $(0.07 \mathrm{US} \$ / \mathrm{kW} \mathrm{h})$. It can be observed that the value found in this paper is slightly different from the one calculated by Cruz [27] due to the fact that exergetic cost which was calculated in this study takes into account all irreversibilities of the system.

\section{Conclusion}

Despite the fact that the functional diagram is very complex, it is useful for energy efficiency analysis of hydrogen production in a Biodiesel Plant. The values of exergetic functions associated to thermoeconomic functional diagram were also determined. In this analysis, the highest values of exergetic functions are associated to canola oil, biodiesel and hydrogen flows. In this sense, supported by the analysis, it can be affirmed that the simultaneous production of Biodiesel and Hydrogen is a technology that offers technical viability.

According to Eq. (82) that has been obtained in this paper, for the purpose of decreasing the final product costs within the biodiesel production plant, the hydrogen production technology has been incorporated to the plant, making possible the energetic use of glycerine. Based on Eq. (82) and Fig. 6, the biodiesel production 
cost reduction can reachs $6 \%$ when compared to values reported by Coronado. The hydrogen production costs as it is shown in Fig. 7, they are very close to the values reported in the literature. Biodiesel production alone has advantages when comparing with biodiesel and hydrogen simultaneous production due to that their production cost is minor, but in the biodiesel production alone glycerine is obtained. The glycerol crude produced contains lot of contaminants which decreases its quality and has low value, nowadays is relevant the conversion of low value glycerol crude to hydrogen production. The incorporation of hydrogen production in a biodiesel plant indeed offers a brand new and advanced technology for biodiesel production. The findings will assist in the integration of cogeneration system seeking the energetic autosufficiency in the plant. In the next part of the paper will be conducted a life cycle analysis of simultaneous biodiesel and hydrogen production. The carbon dioxide emissions results are compared with other processes of hydrogen production including steam reforming of methane. This part will be submitted in the same journal.

\section{Acknowledgements}

The authors look forward to acknowledge the financial support provided by the Coordination for the Improvement of Higher Level -or Education- Personnel (CAPES).

\section{References}

[1] Y. Zhang, M.A. Dubé, D.D. McLean, M. Kates, Biodiesel production from waste cooking oil: 1. Process design and technological assessment, Bioresour. Technol. 89 (2003) 1-16.

[2] Y. Zhang, M.A. Dubé, D.D. McLean, M. Kates, Biodiesel production from waste cooking oil: 2. Economic assessment and sensitivity analysis, Bioresour. Technol. 90 (2003) 229-240.

[3] C.R. Coronado, C.E. Tuna, R. Zanzi, L.F. Vane, J.L. Silveira, Development of a thermoeconomic methodology for optimizing biodiesel production. Part II: Manufacture exergetic cost and biodiesel production cost incorporating carbon credits, a Brazilian case study, Renew. Sustain. Energy Rev. 29 (2014) 565-572, http://dx.doi.org/10.1016/j.rser.2013.08.06.

4] D.C. Kligerman, E.J. Bouwer, Prospects for biodiesel production from algaebased wastewater treatment in Brazil: a review, Renew. Sustain. Energy Rev. 52 (2015) 1834-1846, http://dx.doi.org/10.1016/j.rser.2015.08.030.

[5] A. Johari, B.B. Nyakuma, S.H. Mohd Nor, R. Mat, H. Hashim, A. Ahmad, et al., The challenges and prospects of palm oil based biodiesel in Malaysia, Energy 81 (2015) 255-261, http://dx.doi.org/10.1016/j.energy.2014.12.037.

[6] M. Olkiewicz, N.V. Plechkova, M.J. Earle, A. Fabregat, F. Stüber, A. Fortuny, et al., Biodiesel production from sewage sludge lipids catalysed by Brønsted acidic ionic liquids, Appl. Catal. B Environ. 181 (2016) 738-746, http://dx.doi.org/ 10.1016/j.apcatb.2015.08.039.

[7] M. Araque, T.L.M. Martínez, J.C. Vargas, A.C. Roger, Hydrogen production by glycerol steam reforming over CeZrCo fluorite type oxides, Catal. Today 176 (2011) 352-356

[8] F. Díaz Alvarado, F. Gracia, Oxidative steam reforming of glycerol for hydrogen production: thermodynamic analysis including different carbon deposits representation and $\mathrm{CO}_{2}$ adsorption, Int. J. Hydrogen Energy 37 (2012) $14820-14830$.
[9] N. Hajjaji, A. Chahbani, Z. Khila, M.-N. Pons, A comprehensive energy-exergybased assessment and parametric study of a hydrogen production process using steam glycerol reforming. Energy n.d. http://dx.doi.org/10.1016/j.energy. 2013.10.023.

[10] G. Wu, S. Li, C. Zhang, T. Wang, J. Gong, Glycerol steam reforming over perovskite-derived nickel-based catalysts, Appl. Catal. B Environ. 144 (2014) 277-285, http://dx.doi.org/10.1016/j.apcatb.2013.07.028.

[11] S. Adhikari, S. Fernando, S.R. Gwaltney, S.D. Filip To, R. Mark Bricka, P.H. Steele, et al., A thermodynamic analysis of hydrogen production by steam reforming of glycerol, Int. J. Hydrogen Energy 32 (2007) 2875-2880.

[12] C.C.R.S. Rossi, C.G. Alonso, O.A.C. Antunes, R. Guirardello, L. Cardozo-Filho, Thermodynamic analysis of steam reforming of ethanol and glycerine for hydrogen production, Int. J. Hydrogen Energy 34 (2009) 323-332.

[13] S. Authayanun, A. Arpornwichanop, Y. Patcharavorachot, W. Wiyaratn, S. Assabumrungrat, Hydrogen production from glycerol steam reforming for low- and high-temperature PEMFCs, Int. J. Hydrogen Energy 36 (2011) $267-$ 275 .

[14] C.K. Cheng, S.Y. Foo, A.A. Adesina, Thermodynamic analysis of glycerol-steam reforming in the presence of $\mathrm{CO}_{2}$ or $\mathrm{H}_{2}$ as carbon gasifying agent, Int. J. Hydrogen Energy 37 (2012) 10101-10110.

[15] E. Font de Mora, C. Torres, A. Valero, Assessment of biodiesel energy sustainability using the exergy return on investment concept, Energy 45 (2012) 474-480, http://dx.doi.org/10.1016/j.energy.2012.02.07.

[16] R.A.M. Boloy, S.J.R. Ferrán, D.D.C.L. e Penalva, C. Corrêa, J.A.P. Angulo, R. de Castro Pereira Filho, Exergetic evaluation of incorporation of hydrogen production in a biodiesel plant, Int. J. Hydrogen Energy 40 (2015) 87978805, http://dx.doi.org/10.1016/j.ijhydene.2015.04.121.

[17] M.A. Lozano, A. Valero, Theory of the exergetic cost, Energy 18 (1993) 939960

[18] J.R. Camargo, C.D. Ebinuma, J.L. Silveira, Thermoeconomic analysis of an evaporative desiccant air conditioning system, Appl. Therm. Eng. 23 (2003) 1537-1549, http://dx.doi.org/10.1016/S1359-4311(03)00105-4.

[19] I.A.D. Villela, J.L. Silveira, Thermoeconomic analysis applied in cold water production system using biogas combustion, Appl. Therm. Eng. 25 (2005) 1141-1152, http://dx.doi.org/10.1016/j.applthermaleng.2004.08.014.

[20] W.Q. Lamas, J.L. Silveira, G.E.O. Giacaglia, L.O.M. Reis, Development of a methodology for cost determination of wastewater treatment based on functional diagram, Appl. Therm. Eng. 29 (2009) 2061-2071, http://dx.doi. org/10.1016/j.applthermaleng.2008.10.018.

[21] W de O Lamas, J.L. Silveira, G.E. Oscare Giacaglia, L.O. Mattos dos Reis, Thermoeconomic analysis applied to an alternative wastewater treatment, Renew. Energy 35 (2010) 2288-2296.

[22] J.L. Silveira, C.E. Tuna, W. de Queiroz Lamas, I. Aparecida de Castro Villela, A contribution for thermoeconomic modelling: a methodology proposal, Appl. Therm. Eng. 30 (2010) 1734-1740.

[23] C.R. Coronado, C.E. Tuna, R. Zanzi, L.F. Vane, J.L. Silveira, Development of a thermoeconomic methodology for the optimization of biodiesel productionPart I: Biodiesel plant and thermoeconomic functional diagram, Renew. Sustain. Energy Rev. 23 (2013) 138-146, http://dx.doi.org/10.1016/j. rser.2013.02.015.

[24] J.L. Silveira, C.E. Tuna, W.D.Q. Lamas, M.E. Da Silva, V.J. Martinelli, Thermodynamic and economic analysis of hydrogen production integration in the Brazilian sugar and alcohol industry, Renew. Sustain. Energy Rev. 30 (2014) 869-876, http://dx.doi.org/10.1016/j.rser.2013.10.012.

[25] Robert F. Boehm, Robert F. Boehm, Design Analysis of Thermal Systems, Wiley New York, 1987.

[26] R. Kothari, D. Buddhi, R.L. Sawhney, Comparison of environmental and economic aspects of various hydrogen production methods, Renew. Sustain. Energy Rev. 12 (2008) 553-563, http://dx.doi.org/10.1016/j.rser.2006.07.012.

[27] F.E. Da Cruz, Produção De Hidrogênio Em Refinarias De Petróleo : Avaliação Exergética E Custo De Produção Produção De Hidrogênio Em Refinarias De Petróleo : Avaliação Exergética E Custo De Produção, 2010. 